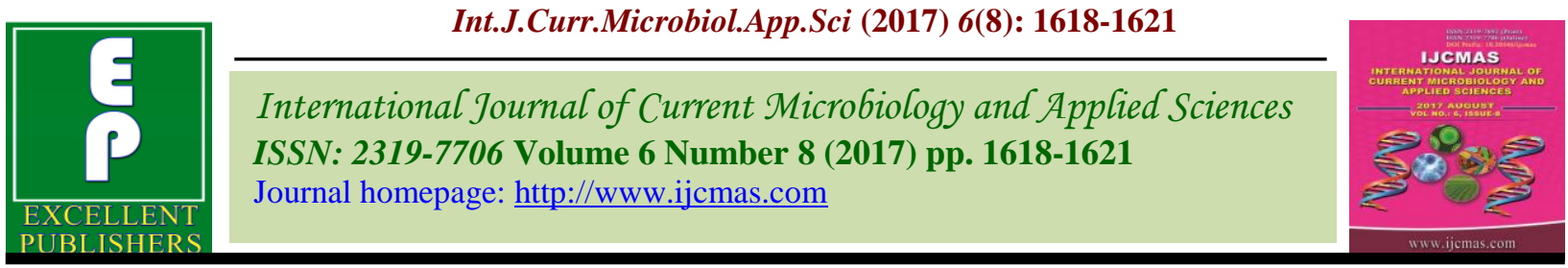

Original Research Article

https://doi.org/10.20546/ijcmas.2017.608.194

\title{
Effect of Conjunctive Use of Phosphorus and Bio-Organics on Phosphorus Content and Uptake in Summer Groundnut (Arachis hypogaea L.)
}

\author{
R.R. Choudhary ${ }^{1 *}$ and H.L. Yadav ${ }^{2}$ \\ ${ }^{1}$ B.A. College of Agriculture, Anand Agricultural University, Anand, 388 110, India \\ ${ }^{2}$ Junagadh Agricultural University, Junagadh, Gujarat, India \\ *Corresponding author
}

\section{A B S T R A C T}

\begin{tabular}{|c|}
\hline Keywords \\
\hline $\begin{array}{l}\text { Groundnut, } \\
\text { Phosphorus, } \\
\text { PSB, } \\
\text { Vermicompost. }\end{array}$ \\
\hline Article Info \\
\hline $\begin{array}{l}\text { Accepted: } \\
\text { 17 June } 2017 \\
\text { Available Online: } \\
10 \text { August } 2017\end{array}$ \\
\hline
\end{tabular}

Keywords

Groundnut, Phosphorus, PSB, Article Info Accepted: Available Online: 10 August 2017

\section{Introduction}

The groundnut (Arachis hypogaea L.) is one of the important food legume crops of tropical and subtropical parts of the world. It is the world's most popular oilseed crop cultivated in more than 100 countries in all the six continents. Groundnut kernel contains above $40 \%$ edible oil, around $25 \%$ protein and $18 \%$ carbohydrates along with minerals and vitamins. Groundnut oil is free from cholesterol and contains less than 20\% saturated fatty acid and hence is heart friendly. Groundnut oil is also considered as the staple and nutritive, as it contains just the right proportion of oleic $(46.5 \%)$ and linoleic (31.4\%) acids (Mathur and Khan, 1997). Phosphorus play beneficial role in the root development, nodulation and stimulation of the symbiotic nitrogen fixation. It enhances root development and nodulation, improves the supply of nutrients and water increase in photosynthetic area resulting in more dry matter accumulation and yield (Rajanikanth et al., 2008). Phosphorous appear to be a limiting factor in yield. It promotes root development, flowering and fruiting and aids in setting of kernels. It is reported (Nair et al., 
1970) that, phosphorus has a very critical role to play in a view of the fact that lack of phosphorus results great reduction in nodulation and nitrogen fixation.

Thus, the phosphatic fertilizers play an important role in achieving higher yield of groundnut crop. Phosphorus fertilization occupies an important place amongst the nonrenewable inputs in modern agriculture. Crop recovery of added phosphorus seldom exceeds 20 per cent and it may be improve by the judicious management. It play beneficial role in the root development, nodulation and stimulation of the symbiotic nitrogen fixation. Phosphate solubilizing bacteria (PSB) are a group of beneficial bacteria capable of hydrolysing organic and inorganic phosphorus from insoluble compounds.

Vermicompost is an odourless, clean, organic material containing adequate quantities of $\mathrm{N}$, $\mathrm{P}, \mathrm{K}$ and several micronutrients essential for plant growth. Humic acid is one of the most important fractions of soil organic matter, it has been reported to increase the yield of crop.

\section{Materials and Methods}

A field experiment was conducted during summer season 2012 at Agronomy Farm, B.A College of Agriculture, Anand Agricultural University, Anand, the soil of the experimental area was loamy sand in texture, low in available nitrogen $\left(178.44 \mathrm{~kg} \mathrm{ha}^{-1}\right)$ and organic carbon $(0.36 \%)$, medium in available phosphorous (30.08 kg ha $\mathrm{kg}^{-1}$ and high in available potassium $\left(358.86 \mathrm{~kg} \mathrm{ha}^{-1}\right)$ with $\mathrm{pH}$ 7.6 .

Twelve treatment combinations comprising three levels of phosphorus viz., control, $25 \mathrm{~kg}$ $\mathrm{P}_{2} \mathrm{O}_{5} \mathrm{ha}^{-1}$ and $50 \mathrm{~kg} \mathrm{P}_{2} \mathrm{O}_{5}$ ha $^{-1}$ and four levels of bio-organics viz., control, PSB seed treatment $5 \mathrm{ml} \mathrm{kg}^{-1}$ seed, vermicompost $2 \mathrm{t} \mathrm{ha}^{-1}$ and humic acid $15 \mathrm{~kg} \mathrm{ha}^{-1}$ were tried in Factorial Randomized Block Design with four replications.

\section{Results and Discussion}

A perusal of data in tables 1 and 2 revealed that phosphorus application significantly influenced on phosphorus content. Treatment $50 \mathrm{~kg} \mathrm{P}_{2} \mathrm{O}_{5}$ ha $^{-1}$ recorded significantly higher phosphorus content in kernels $(0.48 \%)$ but it was remained at par with treatment $25 \mathrm{~kg}$ $\mathrm{P}_{2} \mathrm{O}_{5} \mathrm{ha}^{-1}(0.45 \%)$.

Results indicated that the effects of bioorganics levels in respect of phosphorus content in kernels were found to be significant. Phosphorus content in kernels was significantly higher under treatment vermicompost $2 \mathrm{t} \mathrm{ha}^{-1}(0.48 \%)$ which was remained at par with treatment PSB seed treatment $5 \mathrm{ml} \mathrm{kg}^{-1}$ seed $(0.47 \%)$.

Table.1 Phosphorus content (\%) in kernel of groundnut as influenced by interaction of phosphorus and bio-organics

\begin{tabular}{|l|c|c|c|c|}
\hline \multirow{2}{*}{$\begin{array}{c}\text { Phosphorus } \\
\left(\mathrm{kg} \mathrm{ha}^{-\mathbf{1}}\right)\end{array}$} & Control & $\begin{array}{c}\text { PSB seed treatment 5 ml } \\
\mathrm{kg}^{-1} \text { seed }\end{array}$ & $\begin{array}{c}\text { Vermicompost 2 } \\
\mathrm{t} \mathrm{ha}^{-1}\end{array}$ & $\begin{array}{l}\text { Humic } \\
15 \mathrm{~kg} \mathrm{ha}^{-1}\end{array}$ \\
\cline { 2 - 5 } & 0.40 & 0.41 & 0.45 & 0.44 \\
\hline 0 & 0.41 & 0.53 & 0.47 & 0.41 \\
\hline 25 & 0.45 & 0.48 & 0.54 & 0.44 \\
\hline 50 & \multicolumn{4}{|c|}{0.02} \\
\hline S. Em. \pm & \multicolumn{4}{|c|}{0.06} \\
\hline C.D. $(\mathrm{P}=0.05)$ & 8.52 \\
\hline C.V. \% & \multicolumn{4}{|c|}{} \\
\hline
\end{tabular}


Table.2 Pod yield, haulm yield, P content in kernel and P uptake by kernel of groundnut as influenced by phosphorus and bio-organics

\begin{tabular}{|c|c|c|c|c|}
\hline Treatments & $\begin{array}{c}\begin{array}{c}\text { Pod yield } \\
\left.\text { ha }^{-1}\right)\end{array} \\
(\mathrm{kg}\end{array}$ & $\begin{array}{c}\text { Haulm Yield } \\
\left(\mathrm{kg} \mathrm{ha}^{-1}\right)\end{array}$ & $\begin{array}{c}P \text { content } \\
\text { in kernel } \\
(\%)\end{array}$ & \begin{tabular}{c}
\multicolumn{2}{|c}{ P uptake by } \\
kernel $_{\left.\text {ha }^{-1}\right)}$
\end{tabular} \\
\hline \multicolumn{5}{|l|}{ Phosphorus $\left(\mathrm{kg} \mathrm{ha}^{-1}\right)$} \\
\hline 0 & 2208 & 3754 & 0.42 & 11.41 \\
\hline 25 & 2419 & 4298 & 0.45 & 12.38 \\
\hline 50 & 2657 & 4467 & 0.48 & 13.25 \\
\hline S. Em. \pm & 54.00 & 116.08 & 0.01 & 0.25 \\
\hline C.D. $(P=0.05)$ & 155 & 334 & 0.03 & 0.71 \\
\hline \multicolumn{5}{|l|}{ Bio-organics } \\
\hline Control & 2002 & 3751 & 0.42 & 3751 \\
\hline $\begin{array}{l}\text { PSB seed treatment } 5 \mathrm{ml} \mathrm{kg}^{-} \\
{ }^{-} \text {seed }\end{array}$ & 2588 & 4208 & 0.47 & 4208 \\
\hline Vermicompost $2 \mathrm{t} \mathrm{ha}^{-1}$ & 2631 & 4387 & 0.48 & 4387 \\
\hline Humic acid $15 \mathrm{~kg} \mathrm{ha}^{-1}$ & 2491 & 4346 & 0.43 & 4346 \\
\hline S. Em. \pm & 62.36 & 134.05 & 0.01 & 134.05 \\
\hline C.D. $(\mathrm{P}=0.05)$ & 180 & 386 & 0.03 & 386 \\
\hline C.V.\% & 8.90 & 11.13 & 8.52 & 11.13 \\
\hline \multicolumn{5}{|l|}{ Interaction } \\
\hline $\mathrm{PX} B$ & Sig. & NS & Sig. & NS \\
\hline
\end{tabular}

The results revealed that treatment combination of $50 \quad \mathrm{~kg} \quad \mathrm{P}_{2} \mathrm{O}_{5} \quad \mathrm{ha}^{-1}+$ Vermicompost $2 \mathrm{t} \mathrm{ha}^{-1}$ recorded significantly higher phosphorus content in kernel $(0.54 \%)$. Treatment $50 \mathrm{~kg} \quad \mathrm{P}_{2} \mathrm{O}_{5} \quad \mathrm{ha}^{-1}$ significantly recorded highest phosphorus uptake by kernel. This might be due to the fact that the crop could better take up the said nutrients only when the suitable dose of phosphorus was applied (Deka et al., 2001).

Phosphorus increases the root growth of the crop which ultimately helped in increasing the $\mathrm{P}$ uptake by kernel. This result is in accordance with Jana et al., 1990. Vermicompost increase the availability of phosphorus, which is known to develop a more extensive root system and thus enabling the plants to extract water and nutrients from deeper soil depth (Pattar et al., 1999). These all might have contributed towards increased available phosphorus status of the soil (Kachot et al., 2001).

\section{References}

Deka, N.C., Gogoi, P.K., Pinku Barman and Dutta, R. 2001. Effect of levels of lime and phosphorus on nutrient content and uptake of groundnut. Ann. Agric. Res. New Series, 22(4): 503-507.

Jana, P.K., Ghatak, S., Barik, A., Biswas, B.C., Sounda, G. and Mukherjee, A.K. 1990. Response of summer groundnut to phosphorus and potassium. Indian $J$. Agron., 35(1\&2): 137-143.

Kachot, N.A., Malavia, D.D., Solanki, R.M. and Sagarka, B.K. 2001. Integrated nutrient management in rainy-season groundnut (Arachis hypogaea). Indian J. Agron., 46(3): 516-522.

Mathur, R.S. and Khan, M.A. 1997. 
Groundnut is poor men's nut. Indian Farmer's Digest, 30(5): 29 - 30.

Nair, K.S., Ramaswamy, P.P and Perumal, R. 1970. Nutritional factors affecting nitrogen fixation in (Arachis hypogaea L.). Madras Agric. J., 57(6): 307-310.

Pattar, P.S., Nadagouda, V.B., Salakinkop, S.R., Kannur, V.S. and Gaddi, A.V., 1999. Effect of organic manures and fertilizers levels on nutrient uptake, soil nutrient status and yield of groundnut (Arachis hypogaea L.). J. Oilseeds Res., 16(1): 123-127.

Rajanikanth, E., Subrahmanyam, M.V.R. and Rao, J.V. 2008. Effect of integrated nutrient management practices on growth and yield of rainfed groundnut (Arachis hypogaea L.) intercropped with guava, Psidium guajava. Oilseeds Res., 25(2): 157-160.

\section{How to cite this article:}

Choudhary, R.R. and Yadav, H.L. 2017. Effect of Conjunctive Use of Phosphorus and BioOrganics on Phosphorus Content and Uptake in Summer Groundnut (Arachis hypogaea L.). Int.J.Curr.Microbiol.App.Sci. 6(8): 1618-1621. doi: https://doi.org/10.20546/ijcmas.2017.608.194 